\title{
RESEARCH ON EXPLORING THE FORMATION FACTORS OF YOUTH ENTREPRENEURSHIP SATISFACTION AND BEHAVIOR INTENTION
}

\author{
Liu FENG ${ }^{1}$ - Song XIAO-TING ${ }^{2}$ \\ ${ }^{1}$ School of Public Affairs \& Law, Southwest Jiaotong University, Chengdu, Sichuan 610031, \\ China.E-mail: phoenix820217@126.com (corresponding author) \\ ${ }^{2}$ School of Public Affairs and Law, Southwest Jiaotong University, Chengdu, Sichuan 610031, \\ China.E-mail: yolanda956@foxmail.com
}

\begin{abstract}
This research established the youth entrepreneur satisfaction forming path and behavior intention model on the base of classical customer satisfaction index model, and took the 172 youth entrepreneurs as research object, who have been supported by China Youth Entrepreneurship Program (YBC) Mianyang Office since 2007. This study applies factor analysis and structural equation model to reveal the satisfaction formation mechanism which affects by the youth entrepreneurs expectations, guidance quality and guidance value perception, as well as the entrepreneurs' subsequent behavior affected by the satisfaction. The results show that the mentor image has significantly positive effect on the youth entrepreneur expectation. The latter affects the satisfaction through the guidance quality perception to exert influence on the youth's guidance value perception; youth entrepreneur expectation, guidance value perception and guidance quality perception have positive effects on satisfaction. As for the youth entrepreneurs' behavioral intention, the youth's satisfaction had significantly negative effects on their complaint and significantly positive effects on their loyalty. In addition, there were significantly negative effects between the youth entrepreneurs' complaint and loyalty.
\end{abstract}

Keywords: youth entrepreneur, entrepreneurship mentors, satisfaction model, behavioral intention

\section{INTRODUCTION}

The $18^{\text {th }}$ National Congress of the Communist Party of China (2014) reported that the entrepreneurship was the endogenous power for economic and social sustainable development, as well as the main source to create jobs, moreover the primal power for industrial upgrading and social transformation. In order to promote 
entrepreneurship, especially the youth entrepreneurship, the 18th CPC Congress indicated that the Party should make more effort to support the young generation to start up their business.

The "Global Entrepreneurship Monitor China Report: business environment and policy", which was released by the Entrepreneurship Research Center, Tsinghua University, reported that almost $40 \%$ Chinese possessed entrepreneurial skills and experiences, but the entrepreneurial environment in China, including the aspects of financial support, government policies, government programs, education and training, research and technology transfer, ranked No. 36 among 69 participation in Global Entrepreneurship Monitor, well below the United States, Singapore, Switzerland, Finland and other countries in the top of the rank. Thereinto, entrepreneurship education and training is an extremely weak sector.

Viewing the experience of entrepreneurship promotion all over the world, entrepreneurship mentor is a kind of commonly used approach in the entrepreneurship promotion program to support the novice entrepreneurs in the years following the starting of their business by pairing up a novice entrepreneur with an experienced entrepreneur, who provides advice, know-how and even various resource to help the novice avoid costly or even fatal mistakes (Sullivan 2000). For example, the American SCORE (Service Corps of Retired Executives) program, which is sponsored by Small Business Administration (SBA) in the seventies, has established a giant volunteer mentors network with over 12,000 mentors and has already supported more than eight million small business managers. Other similar initiatives, such as the Business Link in England, the Mentor Eget Företag program in Sweden, the France Initiative and the Canada Fondation de l'entrepreneurship network, all have contributed to upgrade the survival rate of the start-up business by the guidance service of the mentors.

Some studies suggest that entrepreneurship mentors possess abundant experience, knowledge and resource of starting-up business (Xinhua 2012; Baron et al. 2009). In addition, Shieh (2014) indicated entrepreneurship has important knowledge for business restarts of micro and small enterprises which is a key factor in economic development promotion. The youth entrepreneurs may benefit from many types of different outcome, including cognitive learning (Cui and Zhang 2013; Ying and Ma 2011; Bisk 2002), affective support ( $\mathrm{Li}$ and $\mathrm{Lu}$ 2010; Guidance ... 2013; Zhang and Huang 2013), policy-making consulting (Liu et al. 2013; Zhe and Luo 2013; Cull 2006), new contact network (Li and Qin 2014), leadership learning (Ozgen and Baron 2007; Chang and Polonsky 2012) and sales and profit improvement (Chen et al. 2014), even the satisfaction being entrepreneurs. St-Jean's further research (2012) explored and validated the psychological functions (reflector, reassurance, motivation and confidant), four 
entrepreneurial career-related functions (integration, information support, confrontation and guide) and a role model function of the mentors.

Although outcomes for the novice entrepreneur and function of the mentors are better known, the process of entrepreneurship mentorship are practically unknown so far. Especially the research of entrepreneurship mentorship is scarce in China's context. In the mentorship process, have the mentors played effective function? Has the youth entrepreneur expectation been satisfied? What are the influence factors of the youth entrepreneur satisfaction? All these questions have not been answered yet. Therefore, the present study attempted to answer these questions by an exploratory analysis and confirmatory study of youth entrepreneur satisfaction and their behavior intention. A "bottom-up" entrepreneurial mentoring performance feedback system will be built in order to analyze the precise relations among related factors. The results are expected to have theoretical reference value and practical significance for entrepreneurship promotion agencies to improve service quality and entrepreneurial guidance mode, and enhance mentors' guidance level.

\section{LITERATURE REVIEW}

\subsection{Customer satisfaction index (CSI)}

The concept of youth entrepreneur satisfaction (YES) index in this research derived from the concept of customer satisfaction index (CSI). Denstadli and Jacobsen (2011) concluded that customer satisfaction was a state of mind, which was formed by consumers' expectations in line with the consumers' experience; Ferguson et al. (2010) demonstrated that customers' satisfaction was based on customers' past experience to measure the products and services and finally formed an overall evaluation on consumption experience. Terblanche (2013) also stated that satisfaction has the strongest relationship with customer experiences. Ferguson et al. (2010) considered that customers' satisfaction resulted from the customers' purchase and the result of use of the service, when the customers recognized more of the service, they would be more satisfied, whereas they were not satisfied..

Han et al. (2011) argued that CSI was overall subjective emotion and rational state of consciousness which was originated from the evaluation process after buying a product or service. He et al. (2012) considered the CSI can be analyzed from two aspects: (1) to understand customers' satisfaction level with products and services provided; (2) to understand customers' perception and assessment to overall organization. Lee and Shen (2013) took customer' satisfaction as the key 
for quality improvement, and insisted on the factors in customers including (2) the quality of the service structure, such as the cleanness of facilities, convenience of traffic facilities, qualities of the servant and the care degree for customers' benefits; (3) the quality of service outcome - the overall awareness for service.

\subsection{Theoretical model and hypothesis}

Hu et al. (2014) argued that the core of the CSI is based on comparable evaluation of the gap between the expectation to the products before the activity of purchase and the perception after consumption. The core essence of satisfaction degree is a kind of evaluation based on comparison. In terms of the youth entrepreneur satisfaction, it is the gap between expectation and perception of entrepreneur mentor's service which can reflect the youth entrepreneurs' emotion after the mentor's service. For the YES index, international and domestic academics mainly focus on two points, one is the influential factors of YES; the other is the consequent factors of the YES, namely the relationship between YES and its behavior intention.

Jin et al. (2012) found that the youth protégé's satisfaction is mainly influenced by the youth protégé's expectations, the quality of the mentor's guidance (Kenny 2010; Marques and Brandão 2010), such as the mentor's competence (Li et al., 2010), and the mentor's personality (Mazaheri et al. 2010), the youth's perception of the guidance (Wang et al. 2010) and the matched pair between mentor and protégé (Wang et al. 2010; St-Jean and Audet 2013). For the research of satisfaction consequences, the relationship between satisfaction and loyalty generally is divided into two types: one is represented by Kenny (2010), who considered that satisfaction leads to more loyalty; the other is represented by Chang and Polonsky (2012), who argued that satisfaction might not lead to loyalty; Brown and Mazzarol (2009) regarded that customers satisfaction affected their complaint degree negatively; while an empirical study from $\mathrm{Wu}$ (2013) also found that customer satisfaction has significantly negative effect on customer complaints.

Using the scientific literature on mentorship for reference, this paper established a model for the YES and their behavioral intention based on the Swedish customer satisfaction index model (SCSB), the American customer satisfaction index model (ACSI) and the European customer satisfaction index model (ECSI) (as Figure 1 shows), which mainly consists of seven latent variables, including mentor image, youth entrepreneur expectation, guidance quality perception, guidance value perception, YES, youth entrepreneur complaints and youth entrepreneur loyalty. Among them, the youth entrepreneur expectation, guidance quality perception and guidance value perception are causal variables of YES, the 


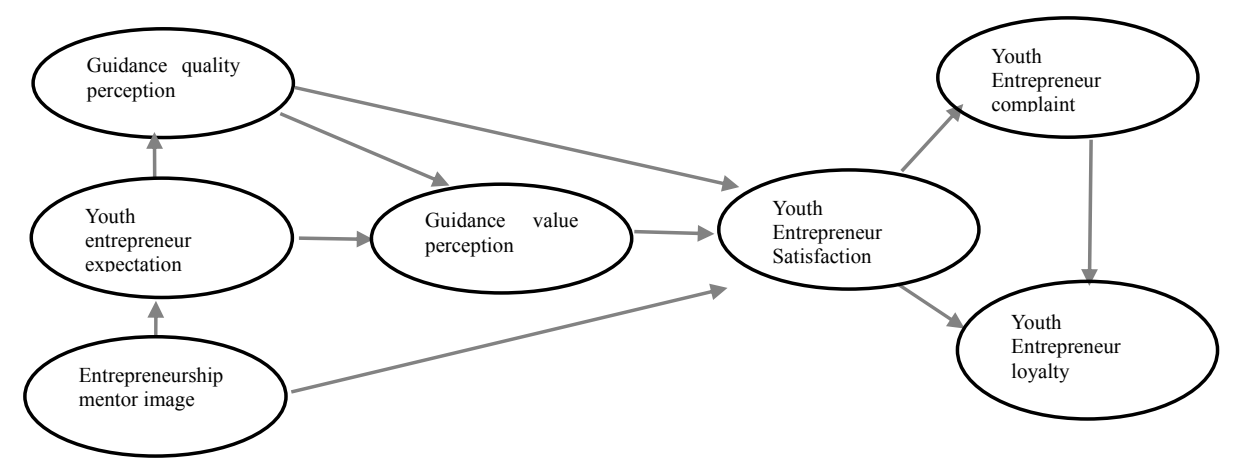

Figure 1. YES form path and behavior intention model

youth entrepreneur complaint and loyalty are outcome variables of satisfaction, causal variables affect the outcome variables comprehensively. According to the causal relations among these structure variables, this research proposed the following hypothesis:

H1: Mentor image has significant positive effect on youth entrepreneur expectation;

$\mathrm{H} 2$ : Youth entrepreneur expectation has significant positive effect on guidance quality perception;

H3: Guidance quality perception has significant positive effect on guidance value perception;

H4: Youth entrepreneur expectation has significant positive effect on guidance value perception;

H5: Youth entrepreneur expectation has significant positive effect on youth entrepreneur satisfaction;

H6: Guidance quality perception has significant positive effect on youth entrepreneur satisfaction;

H7: Guidance value perception has significant positive effect on youth entrepreneurship satisfaction;

H8: Youth entrepreneur satisfaction has significant positive effect on youth entrepreneur complaints;

H9: Youth entrepreneur satisfaction has significant positive effect on youth entrepreneurs loyalty;

H10: Youth entrepreneur complaints have significant positive effect on youth entrepreneur loyalty. 


\section{SAMPLES AND RESEARCH METHODS}

\subsection{Operation definition}

(1) Mentor's image

The mentor's image, consisting of the outer image and personal characteristics, is the youth entrepreneur's first impression of the mentor's guidance idea, behavior, status, and achievement before their mentor-protégé relation is formally established no matter the mentor was allocated by the organization or selected by the youth himself/herself. Mentor image reflects the mentor's quality performance holistically and systematically (St-Jean and Audet 2013). Specifically, mentor's image can be measured by his/her overall image, moral character and work ethic (Li et al. 2010). The youth's impression of the mentor's image will not only directly affect youth's choice, but also affect the expectation indirectly, thereby affect their judgment of guidance service.

\section{(2) Young entrepreneur expectation}

As the Clayton Alderfer's ERG theory mentioned, all human being has the requirement of existence, relationship and growth development. When their lower level needs are achieved, they would pursuit higher level requirement. Likewise, youth entrepreneurs have different expectation on the mentors' guidance in different entrepreneurial stages. In the start-up stage, they are more eager to obtain basic material survival skills, yet in the later stage they might desire deeper knowledge and skill of growth and development with the help of mentors.

Therefore, this paper referred to the three dimensions of Wang and Luo's research (2013) and used the Likert 5 scale to measure the youth entrepreneur expectation. Among them, obtaining basic knowledge of entrepreneurship, improving project management ability, finding out the existing problems, obtaining supervision and guidance stand for the survival safety expectations; caring for each other, becoming friends and intimate trust relationship represent the interpersonal expectation; spreading popularity, expanding customer circle, developing projects and achieving investment opportunities represent growth expectations.

\section{(3) Guidance quality perception}

Guidance quality perception is the quality evaluation of the mentor's guidance service after the youth entrepreneur received the guidance service. In terms of the mentor guidance quality factors, this research adopted 12 measurement variables based on Li et al.'s research (2010) about the mentor's competency which includes mentor character, guidance ability, guidance skill and service skill, among which, mentor character was measured by resource provision, difficulty resolve 
and psychological support. Guidance skills include entrepreneurial knowledge, entrepreneurial management skill and entrepreneurial guidance experience (Denstadli and Jacobsen 2011); service skill includes active care, personal demonstration, communication skills, influence ability and presentation skills (Deakins et al. 1998; Gravells 2006; Güntert et al. 2014).

(4) Guidance value perception

Li and Qin (2014) considered that guidance value perception was a kind of overall evaluation to mentors' guidance utility. This research quoted the dimensions and items from $\mathrm{Hu}$ et al. (2014), which includes the entrepreneurial ability promotion and business project appreciation.

(5) Youth entrepreneur satisfaction

Scholars believed that satisfaction is formed through a two-phase process. Customers will have some expectation for the performance before receiving the service. The gap, namely "inconsistent" will appear when they compare the expectation with the practical performance after their consumption activity. This study cited the three dimensions to measure satisfaction from Cui and Zhang (2013). One is the satisfaction feedback of the youth entrepreneur to the mentors' guidance service holistically; the second is the comparison between the expectation and the actual performance; the last is the comparison between the ideal situation and actual performance.

(6) Youth entrepreneurship complaints

Liu and Chen (2013) proposed two kinds of observation methods for the youth entrepreneurs' complaints: the formal one is that the youth complain to the mentors and ask to improve; the informal one is that they propagandize everywhere and form the word of mouth of their mentor in the masses.

(7) Youth entrepreneur loyalty

Jin et al. (2012) mainly divided loyalty degree into two categories: one is that loyalty is a type of attitude, some kind of feeling about individuals' respect to the service; the other is that loyalty is a type of behavior, which is about that the individual are willing to choose the service repetitively. Therefore, youth entrepreneur loyalty can be reflected from two aspects, the youth has the intention to recommend his/her mentors to others, or choose his/her mentors repeatedly. 


\subsection{The sample}

Youth entrepreneur satisfaction was explored in 2012 and 2013 through mentor and youth entrepreneur discussion groups. In December 2012, data was collected during discussion groups organized to evaluate the YBC mentoring program. The office organized 20 novice entrepreneurs participated to discuss what kind of support they anticipate to obtain from the mentors. Then, a deep discussion group, for a total of 10 mentees was set up: participants were randomly selected from a list of over 120 entrepreneurship mentoring program participants. During the meeting, participants were asked to discuss how they are satisfied with their mentor throughout their relationship. Also, a mentor discussion group which included 6 participants was organized to focus on how they deal with the difficulties the youth entrepreneurs happened. The questionnaire was designed based on the theoretical study and discussion in 2012. Then, the pilot survey was implemented in July 2013, 20 youth entrepreneurs were selected randomly to complete the questionnaire and then the questionnaire was revised and improved according to the analysis result of the pilot survey. From December 2013 to July 2014, the questionnaires were sent to all the participants all over Mianyang area; 134 questionnaires were asked to complete face to face, the other 38 questionnaires were sent by e-mail to the interviewees who can not attend the face to face interview due to various reasons. In all, out of 172 persons, 160 completed the questionnaires which represents a response rate of $93 \%$, and, deleting the questionnaires with errors or uncompleted or inconsistent, finally 152 valid questionnaires were collected.

\section{EMPIRICAL ANALYSIS}

\subsection{Factor analysis}

SPSS19.0 was used to conduct exploratory factor analysis. KMO and Bartlett Test of Sphericity for all observation items of the seven latent variables were conducted before the factor analysis. The results showed that KMO value was 0.813 and the significant value of Bartlett test was 0.000. In addition, the questionnaire already has high content validity by the test and correction after case interview and pilot survey. The structure validity was amended by principal component analysis (PCA). The load coefficient of normalization factor is around 0.718 to 0.956 , greater than 0.5 , which meant that each observation variable could explain the latent variables reliably. Therefore, the model is judged quite acceptable and no modifications were required. 
Analysis of the Cronbach's alpha revealed a result of 0.917 , which indicated that the questionnaires were holistic reliable. And analysis of Cronbach's alpha of each latent variable, each of them is between 0.826 and 0.920 , which meant that the questionnaire's contents were reasonable and all constructs are still strongly corrected.

\subsection{Structural equation model test}

(1) Model fitting inspection and correction

The goodness-of-fit of structural equation model mainly is reflected through relative chi-square (CMIN/DF), RMSEA, root mean square residual (RMR), goodness-of-fit index (GFI), adjusted goodness of fit index (AGFI), standard fitting index (NFI), non-standard fitting index (TLI). From the result of revised model (Table 1), all evaluation indicators are in the range of recommended values, which means that goodness-of-fit is reliable, and path analysis can be performed.

Table 1. The revised model goodness-of-fit

\begin{tabular}{ccccccccc}
\hline & CMIN/DF & RMSEA & RMR & GFI & AGFI & NFI & TLI & NFI \\
\hline Correction model & 1.402 & 0.038 & 0.032 & 0.922 & 0.926 & 0.927 & 0.988 & 0.993 \\
\hline
\end{tabular}

(2) Youth entrepreneur satisfaction formation

Model tested (Table 2 and Figure 2) suggested that mentor image has significantly positive influence on youth entrepreneur expectations $(\mathrm{P}<0.01)$, and the standard path coefficient is $0.162, \mathrm{H} 1$ is valid. Youth entrepreneur expectation has significantly positive influence on guidance quality perception $(\mathrm{P}<0.01)$, and the path coefficient is 0.337 , which indicates that $\mathrm{H} 2$ is correct guidance quality perception has significantly positive influence on guidance value perception ( $\mathrm{P}<0.01)$, and the path coefficient is 0.508 , which indicates that $\mathrm{H} 3$ is correct. Youth entrepreneur expectations have significantly positive influence on guidance value perception ( $\mathrm{P}<0.01)$, and the path coefficient is $0.0237, \mathrm{H} 4$ is correct. Guidance quality perception has significantly positive influence on youth entrepreneur satisfaction $(\mathrm{P}<0.01)$ and the influence coefficient is 0.876 , which explains that the youth's practical performance can also affect their satisfaction, it means that $\mathrm{H} 5$ is proved. Guidance value perception has significantly positive influence on youth entrepreneur satisfaction $(\mathrm{P}<0.01)$, and the path coefficient is 0.364 , indicating that the higher guidance value perception, the higher youth entrepreneurship satisfaction; the result supports H6. 
In addition, mentor image does not have significant effect on youth entrepreneur satisfaction (path coefficient equals $0.121, \mathrm{P}=0.086>0.01$ ), which means that $\mathrm{H} 7$ is invalid.

(3) Young entrepreneur behavior intention

Table 2 and Figure 2 show that the youth entrepreneur satisfaction has significantly negative influence on youth entrepreneurship complaints $(\mathrm{P}<0.01)$, and the influence coefficient is -0.703 , supporting $\mathrm{H} 8$; youth entrepreneur satisfaction

Table 2. Model path coefficient and significance test

\begin{tabular}{|c|c|c|c|c|c|c|c|c|}
\hline & & & 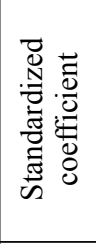 & 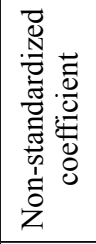 & S.E. & C.R. & $\mathrm{P}$ & Result \\
\hline $\begin{array}{l}\text { Youth } \\
\text { entrepreneur } \\
\text { expectation }\end{array}$ & $<---$ & Mentor image & .162 & .215 & .067 & 3.208 & .002 & H1 valid \\
\hline $\begin{array}{l}\text { Guidance } \\
\text { quality } \\
\text { perception }\end{array}$ & $<---$ & $\begin{array}{l}\text { Youth entrepre- } \\
\text { neur expectation }\end{array}$ & .337 & .412 & .091 & 4.527 & $* * *$ & $\mathrm{H} 2$ valid \\
\hline $\begin{array}{l}\text { Guidance value } \\
\text { perception }\end{array}$ & $<---$ & $\begin{array}{l}\text { Guidance quality } \\
\text { perception }\end{array}$ & .508 & .606 & .068 & 8.911 & $* * *$ & H3 valid \\
\hline $\begin{array}{l}\text { Guidance value } \\
\text { perception }\end{array}$ & $<---$ & $\begin{array}{l}\text { Youth entrepre- } \\
\text { neur expectation }\end{array}$ & .237 & .294 & .083 & 3.542 & $* * *$ & H4 valid \\
\hline $\begin{array}{l}\text { Youth } \\
\text { entrepreneur } \\
\text { satisfaction }\end{array}$ & $<---$ & $\begin{array}{l}\text { Youth entrepre- } \\
\text { neur expectation }\end{array}$ & .876 & 1.003 & .124 & 8.088 & $* * *$ & H5 valid \\
\hline $\begin{array}{l}\text { Youth } \\
\text { entrepreneur } \\
\text { satisfaction }\end{array}$ & $<---$ & $\begin{array}{l}\text { Guidance quality } \\
\text { perception }\end{array}$ & .364 & .455 & .070 & 6.500 & $* * *$ & H6 valid \\
\hline $\begin{array}{l}\text { Youth } \\
\text { entrepreneur } \\
\text { satisfaction }\end{array}$ & $<---$ & $\begin{array}{l}\text { Guidance value } \\
\text { perception }\end{array}$ & -.121 & -.207 & .142 & -1.458 & .086 & H7 invalid \\
\hline $\begin{array}{l}\text { Youth } \\
\text { entrepreneur } \\
\text { complain }\end{array}$ & $<---$ & $\begin{array}{l}\text { Youth entrepre- } \\
\text { neur satisfaction }\end{array}$ & -.703 & -.639 & .099 & -6.454 & $* * *$ & H8 valid \\
\hline $\begin{array}{l}\text { Youth } \\
\text { entrepreneur } \\
\text { loyalty }\end{array}$ & $<---$ & $\begin{array}{l}\text { Youth entrepre- } \\
\text { neur satisfaction }\end{array}$ & .697 & 0.881 & .088 & 10.011 & $* * *$ & H9 valid \\
\hline $\begin{array}{l}\text { Youth } \\
\text { entrepreneur } \\
\text { loyalty }\end{array}$ & $<---$ & $\begin{array}{l}\text { Youth entrepre- } \\
\text { neur complain }\end{array}$ & -.435 & -.541 & .105 & -5.154 & $* * *$ & H10 valid \\
\hline
\end{tabular}

Note: *** means significantly at $\mathrm{P}<0.001$ level 


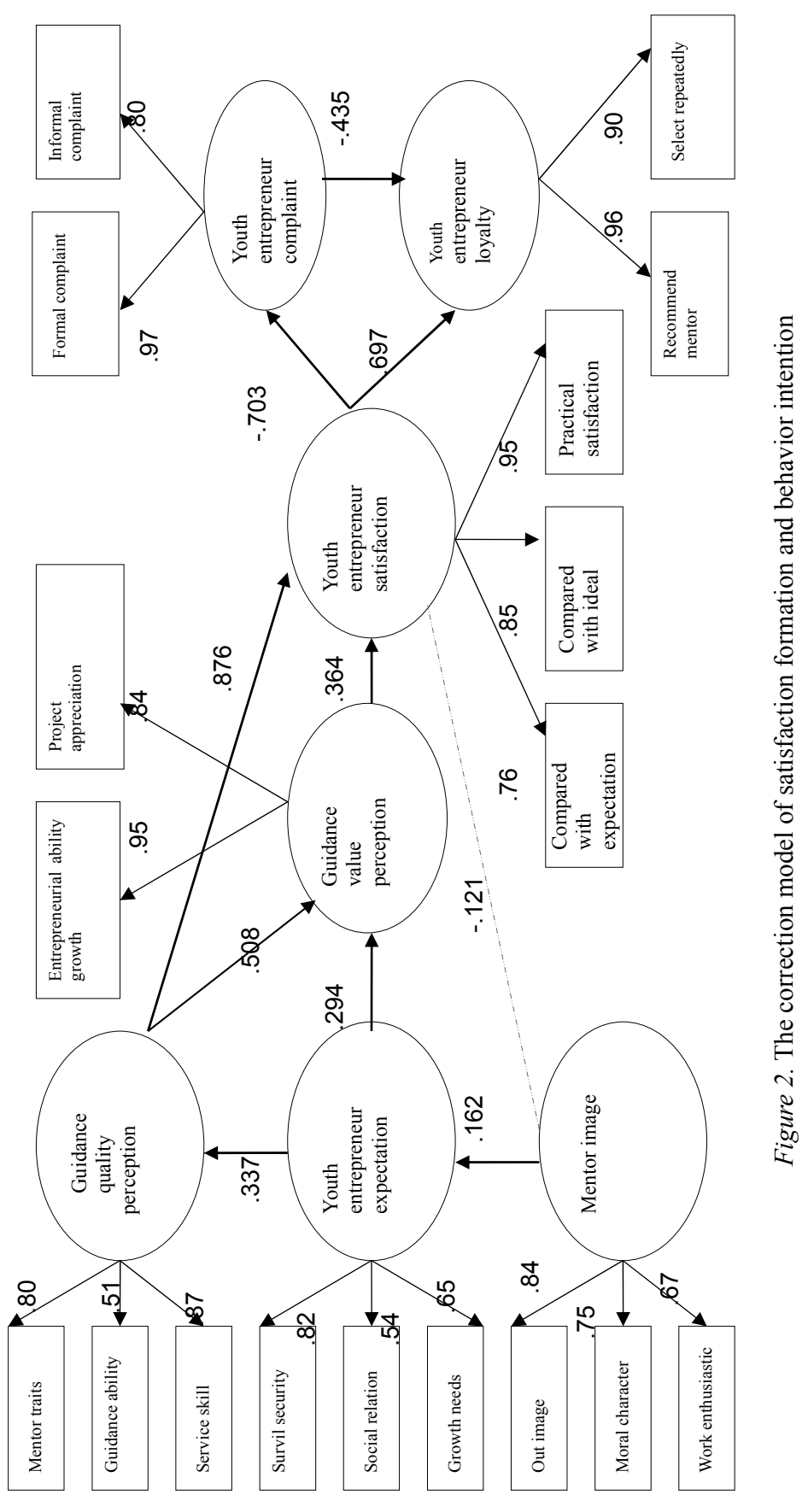


has significant positive influence on youth entrepreneurship loyalty $(\mathrm{P}<0.01)$ and the influence coefficient is 0.697 , supporting H9; In addition, youth entrepreneurship complaints have significant negative effects on youth entrepreneurship loyalty $(\mathrm{P}<0.01)$ and the influence coefficient is -0.435 , supporting H10.

\section{CONCLUSION}

The analysis described above explored the youth's expectation, perception, and satisfaction to their mentors, as well as the correlations among satisfaction, complaints and loyalty by the methods of factor analysis and structural equation model on the basis of young entrepreneur satisfaction formation path and behavior intention model. The results show:

(1) The formation of youth entrepreneur satisfaction was affected by mentor image, youth entrepreneur expectations, guidance quality perception and guidance value perception. Mentor image affects the youth entrepreneur expectations, youth entrepreneur expectations have an effect on the satisfaction through the guidance value perception influenced by the guidance quality perception generally. Besides, youth entrepreneur expectations had significant positive effect on guidance value perception, so did guidance value perception to the youth entrepreneur satisfaction. Mentor image does not have significant effect on youth entrepreneurship satisfaction, the influence coefficient was -0.121 , which could not pass the path test. From the path coefficient, guidance value perception exerted the greatest impact on youth entrepreneur satisfaction, which fully showed the mentor's personal traits, guiding ability and service skills played the most important role in the formation of youth entrepreneur satisfaction.

(2) Complaints and loyalty are different attitude and behavior for young entrepreneurs in different satisfaction degree, which is considered as the result effect of the youth entrepreneur satisfaction. In this study, youth entrepreneur satisfaction has significant negative influence on youth entrepreneur complaints, but it has remarkable positive influence on youth entrepreneur loyalty; youth entrepreneur complaint has a significant negative relationship with youth entrepreneur loyalty. Therefore, if the organizations want to increase youth's loyalty and reduce the complaints, the entrepreneurial guidance satisfaction should be advanced.

(3) Not only the youth's practical expectation can be explored, but also the youth's feedback on mentor's guidance quality perception can be revealed from the formation of youth entrepreneur satisfaction. Therefore, if the mentors want to guide perfectly, they should offer appropriate service to meet the youth's needs and constantly adjust guidance service skills according to the practical situation. 


\section{IMPLICATION}

According to this research, guidance quality perception has significant impact on guidance value perception, and its path coefficient is 0.508 , which has the largest influence on youth entrepreneur satisfaction. Therefore, for improving the quality of entrepreneurship guidance, this study put forward the following suggestions:

(1) A set of thorough entrepreneurship education and training program (EETP) is necessary for the youth entrepreneur cultivation. More appropriate EETP could be inclined to providing youth entrepreneurs according to their needs if young entrepreneurs' attributes, including their personal traits (e.g., thinking style, openness to experience, innovative behavior) and the relationship with their job specifications are well known before the implementation of EETP. To do so, entrepreneurial guidance quality perception might be upgraded through more suitable EETP.

(2) Universities should promote the construction and development of youth entrepreneur mentor system actively. It is necessary to employ entrepreneurs, successful founders, experts and scholars as part-time mentors to undertake the teaching task and lectures; to guide the professional teachers, careers teachers, carry out innovative entrepreneurship education theory and case study actively; to enhance the consciousness and ability of innovation and entrepreneurship education for the teachers who are engaged in professional education and careers guidance education, facilitate these teachers to join the field practice in enterprises, furthermore, universities should provide some preferential policies in the field of teaching evaluation, professional title evaluation, training, financial support and so on to establish a professional and part-time high-qualified innovative entrepreneurship education teachers team, then advance the holistic entrepreneurial guidance quality perception.

(3) For the sake of building a comprehensive entrepreneurship guidance service system, a "national youth entrepreneurship development center" should be established to promote the further collaborative innovation between the government and enterprises. On the one hand, entrepreneurial guidance service theory research should be strengthened, especially the top-level design of entrepreneurial guidance service system and the overall propulsion research; on the other hand, entrepreneurship research and research achievements transformation should be vigorously promoted, the would-be "national youth entrepreneurship development center" should focus on developing series product and service project, such as incubation, information consulting, training, fund support, financing credit, legal aid, financial support, academic conference to provide better service for the youth, the enterprise and the society, to do so to promote youth's perception of entrepreneurship guidance. 


\section{ACKNOWLEDGEMENTS}

Support project: The National Social Science Fund of China Project: Research of early warning model and settlement mechanism of social conflict based on TRIZ theory (13BGL133); Key Research Institute of Humanities and social science of Sichuan province: Resource-based city development Research center project "Research on evaluation index system of innovation capability of resource-based cities" (ZYZX-ZD-1501)

\section{REFERENCES}

Bisk, L. (2002). Formal entrepreneurial mentoring: the efficacy of third party managed programs. Career Development International, 7(5), 262-270.

Brown, R.M. and Mazzarol, T.W. (2009). The importance of institutional image to student satisfaction and loyalty within higher education [J]. Higher Education, 58(1), 142-167.

Chang, Y.W. and Polonsky, M.J. (2012). The influence of multiple types of service convenience on behavioral intentions: The mediating role of consumer satisfaction in a Taiwanese leisure setting. International Journal of Hospitality Management, 31(1), 107-118.

Chen, C., Liao, J.Q. and Wen, P. (2014). Why does formal mentoring matter? The mediating role of psychological safety and the moderating role of power distance orientation in the Chinese context. The International Journal of Human Resource Management, 25, 1112-1130.

China Global Entrepreneurship Monitor Report: Entrepreneurship Education and Training weak link [DB / OL], China Daily, 2014-01-21 http://www.chinadaily.com.cn/hqgj/jryw/2014-01- 21 / content_11081441.html

Cui Bin and Zhang Yawei (2013). Entrepreneurship education formation mechanism of satisfaction - Empirical analysis based on PLS structural equation model [J]. Entrepreneurship and Innovation, (23), 55-59.

Cull, J. (2006). Mentoring young entrepreneurs: what leads to success? International Journal of Evidence Based Coaching and Mentoring, 4(2), 8-18.

Deakins, D., Graham, L., Sullivan, R. and Whittam, G. (1998). New venture support: an analysis of mentoring support for new and early stage entrepreneurs. Journal of Small Business and Enterprise Development, 5(2), 151-161.

Denstadli, J.M. and Jacobsen, J.K.S. (2011). The long and winding roads: Perceived quality of scenic tourism routes. Tourism Management, 32(4), 780-789.

Ferguson, R.J., Paulin, M. and Bergeron, J. (2010). Customer sociability and the total service experience: Antecedents of positive word-of-mouth intentions. Journal of Service Management, 21(1), 25-44.

Gravells, J. (2006). Mentoring start-up entrepreneurs in the East Midlands-Troubleshooters and Trusted Friends. The International Journal of Mentoring and Coaching, 4(2), 3-23.

Guidance in temporary enterprise tutor Factors and Mechanism of Action [D] affect. (2013). Huazhong University of Science, and $\mathrm{PhD}$ thesis.

Güntert, S.T., Neufeind, M. and Wehner, T. (2014). Motives for event volunteering extending the functional approach. Nonprofit and Voluntary Sector Quarterly, 0899764014527797.

Han, H., Kim, W. and Hyun, S.S. (2011). Switching intention model development: Role of service performances, customer satisfaction, and switching barriers in the hotel industry. International Journal of Hospitality Management, 30(3), 619-629. 
He, Y., Chen, Q. and Alden, D.L. (2012). Consumption in the public eye: The influence of social presence on service experience. Journal of Business Research, 65(3), 302-310.

Hu, C., Wang, S., Yang, C.C. and Wu, T.Y. (2014). When mentors feel supported: Relationships with mentoring functions and protégés' perceived organizational support. Journal of Organizational Behavior, 35, 22-37.

Jin, L., He, Y. and Song, H. (2012). Service customization: To upgrade or to downgrade? An investigation of how option framing affects tourists' choice of package-tour services. Tourism Management, 33(2), 266-275.

Kenny, D.A. (2010). Mediation. Retrieved March 23, 2010, from http://davidakenny.net/cm/mediate.htm

Lee, T.H. and Shen, Y.L. (2013). The influence of leisure involvement and place attachment on destination loyalty: Evidence from recreationists walking their dogs in urban parks. Journal of Environmental Psychology, 33, 76-85.

Li, B.Y. and Qin, X. (2014). Volunteer instructor of Wai Dan Gong of seriously leisure experience, the Garter sports health and leisure journals, 13(2), 207-219.

Li, L.L. (2010). Reminder aromatic, yellow school management model based on the Graduate Faculty Research Competency Model [J]. Degrees and Graduate Education, 7, 13-17.

Li, C.L., Absher, J.D., Zinn, H.C., Graefe, A.R. and Chick, G.E. (2010). A multi-ethnic comparison of perceptions of forest recreation service quality. Journal of Tourism and Leisure Studies, 15(3), 213-238.

Marques, A. and Brandão, A. (2010). Is exit a firm failure? Facts and theory. Acta Oeconomica, 60(4), 405-426.

Mazaheri, E., Richard, M.O. and Laroche, M. (2010). Investigating the moderating impact of hedonism on online consumer behavior. Journal of Global Academy of Marketing Science, 20(2), $123-134$.

Ozgen, E. and Baron, R.A. (2007). Social sources of information in opportunity recognition: Effects of mentors, industry networks, and professional forums. Journal of Business Venturing, 22(2), 174-192.

Shieh, C.J. (2014). The impacts of social network on operating performance in micro-enterprises. Acta Oeconomica, 64(Supplement 2), 229-242.

St-Jean, E. and Audet, J. (2012). The role of mentoring in the learning development of the novice entrepreneur. International Entrepreneurship and Management Journal, 8(1), 119-140.

St-Jean, E. and Audet, J. (2013). The effect of mentor intervention style in novice entrepreneur mentoring relationships. Mentoring \& Tutoring: Partnership in Learning, 21(1), 96-119.

Sullivan, R. (2000). Entrepreneurial learning and mentoring. International Journal of Entrepreneurial Behaviour \& Research, 6(3), 160-175.

Terblanche, N. (2013). The influence of value on loyalty in the supermarket industry. Acta Oeconomica, 63(2), 185-200.

Wang, S., Tomlinson, E.C. and Noe, R.A. (2010). The role of mentor trust and protégé internal locus of control in formal mentoring relationships [J]. Journal of Applied Psychology, 95(2), $358-367$.

Wangxi Z. and Luo, T. (2013). To explore theoretical perspectives ERG sports service, Technology and Services Management Journal, 1(2), 89-104.

Wu, I-L. (2013). The antecedents of customer satisfaction and its link to complaint intentions in online shopping: An integration of justice, technology, and trust [J]. International Journal of Information Management, 33(1), 77-95.

Xinhua. Eighteen report [DB/OL], 2012-11-19 http://www.xj.xinhuanet.com/2012-11/19/ c_113722546_2.htm

Xuxian, Y. and $\bar{M}$ a, Q. (2011). Expectations and perceived service quality, customer satisfaction with the relationship between [J]. Forecast, 30(4), 14-19.

Zhang, B. and Huang, Z-P. (2013). Empirical research universities for undergraduate teaching quality satisfaction and loyalty [J]. Higher Education Development, 19, 31-37. 